\title{
COMPETITIVENESS OF THE UNITED KINGDOM AGRI-FOOD TRADE IN RELATION TO THE EU MARKET
}

\author{
Katarina BARATHOVA *, Artan QINETI
}

\section{Address:}

Slovak University of Agriculture in Nitra, Faculty of Economics and Management, Department of Economic Policy, Tr. A. Hlinku 2, 94976 Nitra, Slovak Republic

*Corresponding author: xbarathovak@is.uniag.sk

\begin{abstract}
The United Kingdom as a member of the EU can enjoy full access to the Single European Market. In terms of agri-food trade, EU is UK's most important partner. However, in June 2016, the UK opted to leave EU. This decision will significantly influence the whole economy of the UK including agri-food trade. The objective of this paper is to examine development and comparative advantages of The UK's agri-food trade with respect to the EU-27 markets. The analysis is based on Balassa index and its stability over the period. The agri-food trade data were acquired from Eurostat Comext database and cover the period 2000-2016. The analysis showed that over the period, the UK was able to retain comparative advantages only in three categories - HS 03 Fish, HS 21 Miscellaneous edible preparations, HS 22 Beverages, spirits and vinegar. In the rest of agri-food commodities the declining trend can be observed and in 2016 the UK had comparative disadvantages in 21 agri-food commodities. Based on the results of regression focused on the stability of distribution of Balassa indices over time, we can conclude that the degree of specialization in the agri-food trade between the United Kingdom and the rest of the EU has been decreasing as the number of commodity groups with a comparative advantage has been declining. With respect to Brexit, the agrarian trade of the UK deserves special attention, because the potential increases in trade costs are expected to affect the UK proportionally more than the EU27.
\end{abstract}

Keywords: agri-food trade, Balassa index, comparative advantage, the United Kingdom JEL: F10, F14, Q17

\section{INTRODUCTION}

International trade continues to be of great importance to the United Kingdom's agri-food sector. Because the UK is a relatively small economy, it needs access to both export and import markets to realize an efficient scale of production and to acquire many of the inputs used by UK producers. Geographical location as well as economic size make Europe the UK's natural trading partner. The importance of geographic factors, such as the distance between countries is one of the most important empirical facts for international trade flows (Anderson, 2011). In 1993, EU launched the single market - the internal market of the European Union, which enables the free movement of goods, services, capital and persons. The EU's single market also involves three tools to boost trade. First, it eliminates tariffs on goods. Second, it provides companies and people with right to sell their goods, services or labour, or to invest, in other member-states. Third, by creation minimum regulatory standards, it reduces the cost of potential exporters having to comply with different national rules of 28 member states (Springford and Tilford, 2014). These tools have made the trade including trade with agri-food products between EU member states easier. However, in June 2016, The United Kingdom decided to leave EU. Despite the fact that the form of the future trade relationship between the UK and EU is subject of ongoing talks and negotiations, it is clear that Brexit will mean the worse conditions of trading relationship than as in case of being a member of EU, especially if the UK will leave single market. Brexit may negatively influence agri-food trade of UK as well, although agri-food products are less traded than manufactured ones, they will be however subject to the largest increases in trade protection, both in terms of tariffs and non-tariff measures (Bellora et al., 2017). This means, that Brexit may hurt the competitiveness of UK on markets of EU. For this reason, the objective of our study was to examine development of trade and competitiveness of The UK's agri-food trade with respect to the EU-27 markets. The analysis is based on Balassa index and its stability over the period.

\section{DATA AND METHODS}

\section{The concept of competitiveness}

The economic literature deals with three different levels of competitiveness: at national level, at industry level and at firm level (Bojnec and Fertö, 2006). According to Pitts and Lagnevik (1998) competitiveness of industry can be seen as the ability to profitably acquire and keep market share in domestic and/or foreign markets. Kim and Marion (1997) defined it similarly, as the sustained ability of a nation's industry or firms to compete with rivals in foreign as well as in domestic markets under conditions of free trade. As stated by Banterle (2005) in order to 
characterize the competitiveness of a particular industry like the food sector it is substantial to consider economictheory references and consequently, the sources of competitiveness concept. The main theory references for competitiveness are based on the concept of comparative advantage. The theory of comparative advantages assumes that international trade between nations occurs due to differences in the relative opportunity costs. This theory says that countries are competitive in those goods and services in which they have a relative cost advantage (Nallari and Griffith, 2011).

This paper analyses the development of agri-food trade of UK and competitiveness of the UK's agri-food commodities with respect to the EU-27 countries. The analysis is based on evaluating indices calculated on trade data gathered from Eurostat Comext database. Analysed time series cover the period 2000 - 2016. Agri-food commodities are classified according to the Harmonised System (HS) into 24 different 2-digit sections. The analysis of competitiveness is useful because in the context of Brexit it might reveal potential problems in the branches of agri-food sector.

Before as well as after the referendum, several studies have been made to assess the potential impacts of Brexit on the whole economy and on specific sectors. These studies vary in methodology but most of them expect substantial negative impacts on the UK as well as on the EU. When evaluating possible impacts, the changes in trade flows and the volume of trade appear to be the most important and apparent. A study by UK Treasury estimates that if the UK retains access to the single market, trade will decrease by around 9 per cent. WTO scenario could bring decline in trade between 17 and 24 per cent (HM Treasury, 2016). Dhingra et al. (2016) expects even higher trade effects: with access to the single market, UK trade could fall by around 14 per cent with the impact rising to over 50 per cent in the WTO case. Specifically agri-food trade and the whole agri-food sector are among the areas of the economy which will be impacted the most. Bellora et al. (2017) estimate that after Brexit agri-food imports of the UK from the EU-27 will decrease by $\$ 34$ billion (62\%) and exports of the UK will decline by $\$ 19$ billion (with the same relative decrease, $62 \%$ ). Part of EU27 exports to the UK will be replaced by approximately 1 $\%$ increase in intra-EU-27 trade as well as by $0.9 \%$ increase in exports to third countries. This trade diversion is partly caused by a loss of UK's competitiveness, due to higher prices of imported intermediary consumptions. As stated by Potton and Webb (2017) another important issue is the Common Agricultural Policy (CAP). Membership of the UK in the EU has provided UK farmers with agricultural support and funding. British farmers receive direct payments and rural development grants worth around $£ 3.3$ billion (in 2016). Therefore leaving the EU will mean that the UK will need to design its own agricultural policy. On the other hand, departure of the UK from CAP means a gap in the next CAP budget which in turn will affect the rest of EU members. Haas and Rubio (2017) estimate this gap to approximately $€ 3$ billion per year. This gap can be compensated either by raising contributions of member states, by cuts in spending or by combination of these two approaches. This may produce tensions among member states. Another threat for agri-food sector stems from possible change in immigration. The United Kingdom already faces labour shortage in agriculture and after Brexit, the situation will be probably even worse. Low unemployment rates, the seasonal nature of farm work and low wages are often cited as key difficulties in attracting domestic pickers (Downing and Coe, 2018). McGuinness and Grimwood (2017) stress that during peak seasons, the agriculture sector is dependent on a large temporary, seasonal workforce of around 75,000 workers - to supplement regular, permanent staff in harvesting crops. It is estimated that $98 \%$ of this number are EU mi grants.

\section{Revealed comparative advantage}

The concept of comparative advantage is the main methodological approach applied for investigation of agrifood trade data. The idea to determine a country's strong sectors by analysing the actual export flows was pioneered by Liesner (1958), who first introduced the concept of revealed comparative advantage. Later Balassa (1965) modified this method and therefore it is also known as Balassa index (Eq. 1).

$B=\left(X_{i j} / X_{i t}\right) /\left(X_{n j} / X_{n t}\right)$

Where: $X$ represents exports, $i$ is a country, $j$ is a commodity, $t$ is a set of commodities, and $n$ is a set of countries. The $B$ index is based on observed trade patterns and it measures a country's exports of a commodity relative to its total exports and to the corresponding export performance of a set of countries.

In our case $X_{i j}$ describes British exports for a particular agri-food product group to the EU-27 countries, while $X_{i t}$ is total agri-food exports of the UK to EU-27. $X_{n j}$ denotes the EU-27's exports for a given agri-food product group and $X_{n t}$ total merchandise exports by EU27 countries, which are used as the benchmark of comparison. We considered only intra-EU trade flows as the analysis is focused on evaluation of relative competitive performance of the UK in the EU market, no consideration was given to the position of extra European countries in the EU market or to extra-EU trade.

If $B>1$, then a comparative advantage is revealed, i.e. a sector in which the country is relatively more specialized in terms of exports. So it reveals higher competitiveness. Values between zero and one indicate comparative disadvantages (Bojnec and Fertö, 2007).

Balassa index is often criticized because it is seen to neglect different effects of agricultural policies and exhibits asymmetric values. Trade structure is distorted by different state interventions and trade limitations, while the asymmetric value of the $\mathrm{B}$ index reveals that it extends from one to infinity if a country enjoys comparative advantage from a product, but in case of comparative disadvantage, it varies between zero and one, which overestimates a sector's relative weight (Jambor, 2013). Moreover, Balassa index does not account for import trade flows.

Over the years, several modifications of RCA index have been developed. In response to criticism about 
symmetry, Yu et al. (2009) proposed the Normalized RCA Index (NRCA), which allows more precise comparisons across time, country and sector. Proudman and Redding (2000) also developed alternative to RCA - Weighted RCA (WRCA) index which is obtained by the normalizing the numerator of the RCA index. However, since the value ranges from 0 to $+\infty$, WRCA has also assymetric problem. Hoen and Oosterhaven (2006) introduced an Additive form of RCA (ARCA) which removes asymmetry. Yu et al. (2009) summarize that while these indices improve certain aspects of Balassa's RCA index, none of them can be used as a general index that is comparable over space and time, but Balassa's RCA index is still useful in assessing whether or not a country has comparative advantage in a commodity. Hinloopen and van Marrewijk (2008) add that the main benefit of this index against its alternative trade indices is its theoretical foundation that changes in the B index are consistent with changes in countries' relative factor-endow ments. The B index can provide useful evidence on the country's agrifood export competitiveness on global markets.

In literature numerous studies have used the Balassa index or its modifications with aim to identify a country's strong sectors. For example, by evaluating three indices export market share (EMS), revealed comparative advantage (RCA) and net export index (NEI), Banterle (2005) analysed the competitive performance of the EU countries for food trade in the European market during the period 1990-2003. Bojnec and Fertő (2015) investigated the competitiveness of agri-food exports of the EU-27 countries on global markets, using the Balassa index over the period 2000-2011. They found that a majority of agrifood products in the EU-27 countries show a comparative disadvantage on global markets. Carraresi and Banterle (2008) measured competitiveness of food industry and agriculture in the EU market over the 1991-2006 period, using trade index RCA (Balassa index) as well as other indices (EMS, RXA, RMA, NEI). The results were concluded by cluster analysis dividing countries with similar trends into three groups. The United Kingdom was included in third group which represented countries with worst performance, meaning that these countries had decreasing indices and showed loss of competitiveness. Jambor and Babu (2016) examined competitiveness of global agriculture using Balassa indices for all countries and agricultural products. Although they used also calculations of NRCA, ARCA, WRCA they focused on RCA index, since other indices provided inconsistent results for their sample.

Indices of RCA are arguably useful as one of the few formal ways of measuring the sector identity and intensity of a country's comparative advantage and disadvantage (Richardson and Zhang, 2001). However, when using the RCA index, there is often question about the stability of this index and perseverance of agri-food trade composition across time. According to Hinloopen and van Marrewijk (2001) there are distinguished at least two types of stability. One is the stability of distribution of the indices from one period to the next, second is the stability of the value of the indices for particular product groups from one period to the next. We decided to examine first type of stability. According to the approach applied by
Dalum et al. (1998) we run the regression analysis, where we used Balassa index (Eq. 2).

$$
B_{i j}^{t_{2}}=\alpha_{i}+\beta_{i} B_{i j}^{t_{1}}+\varepsilon_{i j}
$$

Where: $t_{1}$ and $t_{2}$ describe the start year and the end year, respectively. The value of Balassa index $B$ in year $t_{2}$ for sector $i$ in country $j$, represents the dependent variable. The independent variable is represented by value of Balassa index $B$ in start year $t_{1} . \alpha$ and $\beta$ are parameters of linear regression, $\varepsilon$ is a residual error. If $\beta=1$, then it means an unchanged pattern of $B$ between periods $t_{1}$ and $t_{2}$. In case that $\beta>1$, the existing specialization of the country is strengthened. If $0<\beta<1$, then initial patterns have changed. Sectors with initially low $B$ indices grow over time, while sectors with initially high $B$ indices declined. In situation when $\beta<0$, it is indication of a change in the sign of the index. But Dalum et al. (1998) argues that when $\beta>1$, it is not a necessary condition for growth in the overall specialization pattern. The degree of change also depends on $R^{2}$. According to Cantwell (1989) it is expressed as in Equation 3.

$\frac{\sigma_{j}^{t_{2}}}{\sigma_{1}^{t_{1}}}=\frac{\left|\beta_{j}\right|}{\left|R_{j}\right|}$

Where: $\sigma$ refers to standard deviation of dependent variable and $R$ is the coefficient of correlation from the regression. In case $\beta>R$ (or $\beta / R>1$ ), the standard deviation has increased over time, thus the degree of specialization has increased, while if $\beta<R$ (or $\beta / R<1$ ), the degree of specialization has decreased.

\section{RESULTS AND DISCUSSION}

\section{Agri-food trade of the United Kingdom}

Before analysing the magnitude of Balassa index (RCA), it is good to gain the broad picture of agri-food trade. Therefore we take a look at real development of trade flows of the United Kingdom with EU (in nominal terms). Looking more closely at agri-food trade data of the UK, we can see that the value of total UK agri-food imports from EU and from the rest of the world in 2016 across the 24 chapters of HS2 was 55.7 billion EUR, while the value of UK total agri-food exports reached 25.4 billion Eur. Overall, this suggests that the UK is a net importer of agrifood products, which is also reflected in a total agri-food trade deficit of 30.3 billion EUR in 2016. Both British agri-food imports as well as exports are dominated by trade with the EU. The relationship between the UK and the EU-27 is characterized by a strong dissymmetry. The EU-27, as a whole, is a large market (population more than 445 million people and a GDP of USD 13.8 thousand billion in 2016), while the UK is relatively smaller (a population of 65.6 million people and a GDP of USD 2.6 thousand billion). Thus, the EU-27 represents a large market and outlet for UK exporters. The UK is, in comparison, a small market for EU-27 (even if it represents the main export destination of some agri-food sectors in given EU-27 countries). Despite this, the UK is 
currently the second largest EU country and in terms of trade is closely integrated with the EU-27.

Figure 1 presents the development of UK's exports and imports in the EU-27 markets during the period 20002016. In 2016 British imports of agri-food products from EU member states were 39.5 billion EUR which is almost $71 \%$ of the whole British agri-food imports. The value of UK's agri-food exports to EU in that year reached 15.85 billion EUR ( $62.4 \%$ of the whole UK's export). Compared to level of exports and imports of UK with EU sixteen years ago (2000), the value of both exports and imports with EU has significantly increased. Agri-food imports from EU in 2000 represented 19.37 billion EUR, in 2016 this value was by $103.86 \%$ higher. Agri-food exports of UK to EU over same period increased as well, although less than import. Compared to value 10.3 billion EUR in 2000 , exports in 2016 were higher by $53.87 \%$.

If we look more closely at commodity structure of UK's trade with the rest of EU (according to the international tariff nomenclature for the classification of product HS2), we can see that over the monitored years the category HS 22 Beverages, spirits and vinegar represents the largest component of both UK agri-food exports and imports. In last 10 years, beverages and spirits comprised around $14 \%$ of the total agri-food import from EU-27 and around $20 \%$ of export to EU-27. The second major exported agri-food commodity in 2016 was represented by category HS 21 Miscellaneous edible preparations with export value 1.66 billion EUR. HS 02 Meat and edible meat offal with export value 1.35 billion EUR was the third most exported agri-food commodity in 2016 and the category HS 03 Fish with export value 1.31 billion EUR has the fourth position in exports to EU.

The import side of commodity structure in 2016 is very similar to that of export. The value of import of beverages in 2016 reached 5.54 billion EUR and makes it the most imported commodity. During the sixteen years the second most imported agri-food commodity has not changed and this position belongs to meat. In 2016 the value of meat imports reached 4.21 billion EUR. The other major imported agri-food commodities have been changing over the years. In 2016, preparations of cereals held the third position with imports value 3.31 billion EUR and dairy produce holds the fourth position with imports value 3.04 billion EUR.

\section{RCA index of UK's agri-food trade}

Table 1 presents the results of RCA index for 24 categories of agri-food commodities of the United Kingdom over sixteen years divided into four periods. Results reveal there are only three categories in which the UK was able to retain a comparative advantage during the whole sixteen years period. It is category HS 03 Fish, HS 21 Miscellaneous edible preparations and HS 22 Beverages. As seen earlier in this paper, the category of beverages is the major exported agri-food commodity of the UK accounting for $21 \%$ of the whole agri-food export to EU27 in 2016. The category HS 21 Miscellaneous edible preparations was the second and category HS 03 Fish was fourth most exported agri-food commodity accounting for $10 \%$ and $8 \%$ of the whole agri-food export to EU-27 in 2016, respectively. For this reason, the UK seems to be trading in the right way, since it is exploiting these comparative advantages well with regards to EU. However, the RCA index in category of fish is deteriorating. However, these categories show gradual decline from 2000. Other agri-food categories which used to have a comparative advantage experienced the decrease and in many cases the UK lost comparative advantage on EU-27 market. It means that revealed comparative advantage was not persistent. We can see that from 2000 to 2011 , the UK had a comparative advantage in category HS 19 Preparations of cereals, but from 2012 this RCA index has significantly decreased and the UK lost comparative advantage in this category. The UK used to have a comparative advantage in EU-27 markets in two more categories - HS 09 Coffee, tea, mate and spices and HS 24 Tobacco and manufactured tobacco substitutes, however over time it lost comparative advantage in these categories as well. Especially the category of tobacco experienced a sharp decline. In 2000-2003, the RCA index reached value 1.64 indicating comparative advantage and in 2012-2016 the value of RCA was at very low level 0.33, which means that UK has a comparative disadvantage in this category.

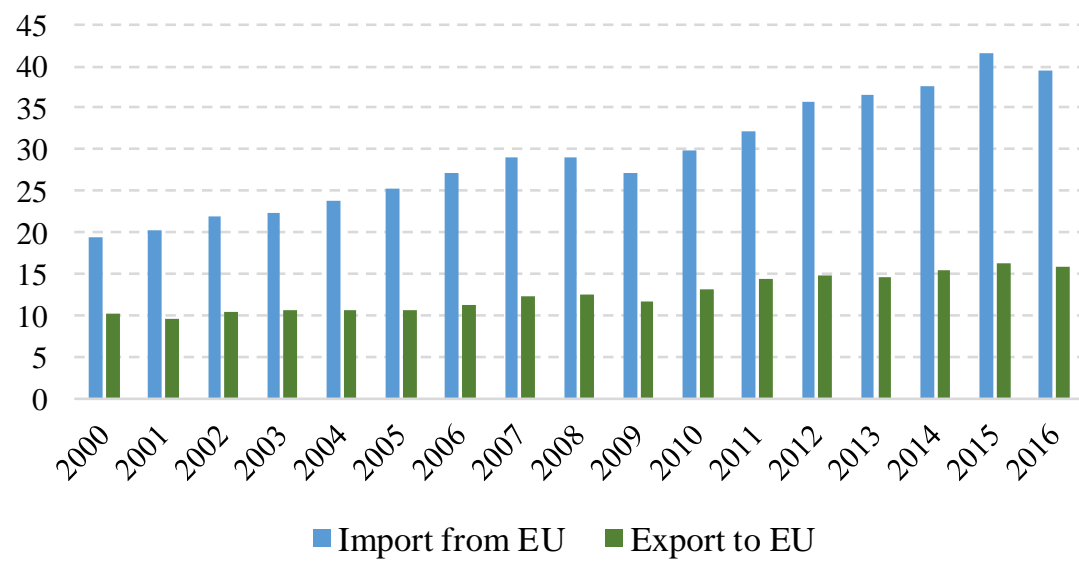

Figure 1 Agri-food trade of the UK with EU (in billion EUR)

Source: own calculation, based on data from Eurostat Comext 
Table 1 Development of the Balassa index for agri-food commodities: The UK - EU-27

\begin{tabular}{lcccr}
\hline Harmonised system/Period & $2000-2003$ & $2004-2007$ & $2008-2011$ & $2012-2016$ \\
\hline 01 Live animals & 0.98 & 0.87 & 0.66 & 0.65 \\
02 Meat and edible meat offal & 0.55 & 0.54 & 0.64 & 0.64 \\
03 Fish etc. & 1.70 & 1.57 & 1.33 & 1.13 \\
04 Dairy produce etc. & 0.62 & 0.60 & 0.52 & 0.57 \\
05 Products of animal origin (nes) & 0.73 & 0.78 & 0.74 & 0.87 \\
06 Live trees and other plants & 0.11 & 0.12 & 0.11 & 0.10 \\
07 Edible vegetables etc. & 0.29 & 0.27 & 0.24 & 0.22 \\
08 Edible fruit and nuts & 0.12 & 0.17 & 0.16 & 0.15 \\
09 Coffee, tea, mate and spices & 1.25 & 0.78 & 0.64 & 0.64 \\
10 Cereals & 1.07 & 0.92 & 0.83 & 0.56 \\
11 Products of the milling industry & 0.99 & 0.75 & 0.78 & 0.78 \\
12 Oil seeds and oleaginous fruits etc. & 0.42 & 0.44 & 0.50 & 0.68 \\
13 Lacs & 0.71 & 0.99 & 1.14 & 0.90 \\
14 Vegetable plaiting materials & 0.20 & 0.34 & 0.38 & 0.72 \\
15 Animal or vegetable fats and oils & 0.76 & 0.69 & 0.54 & 0.50 \\
16 Preparations of meat etc. & 0.61 & 0.61 & 0.56 & 0.47 \\
17 Sugars and sugar confectionery & 0.92 & 0.87 & 0.79 & 0.63 \\
18 Cocoa and cocoa preparations & 0.96 & 0.71 & 0.57 & 0.62 \\
19 Preparations of cereals etc. & 1.67 & 1.36 & 1.07 & 0.97 \\
20 Preparations of vegetables, fruit, etc. & 0.33 & 0.34 & 0.29 & 0.33 \\
21 Miscellaneous edible preparations & 1.47 & 1.20 & 1.11 & 1.37 \\
22 Beverages, spirits and vinegar & 2.35 & 1.99 & 1.99 & 1.87 \\
23 Residues \& waste, prepared animal fodder & 0.85 & 0.71 & 0.71 & 0.78 \\
24 Tobacco and manufactured tobacco substitutes & 1.64 & 1.02 & 0.60 & 0.33 \\
\hline Sour
\end{tabular}

Source: own calculation, based on data from Eurostat Comext database

In most agri-food categories, the RCA index reaches values lower than 1 . The low values imply comparative disadvantage ant therefore these commodities comprise very low share on the export of UK to EU-27. Over the monitored period the UK reached lowest RCA index in category Live trees and other plants $(0.10-0.12)$ as well as in category Edible fruits and nuts (0.12-0.17).

Further, we run the regression analysis to evaluate stability of Balassa index between the years 2000 and 2016. The results show that the value of $\beta$ is 0.2405 . This suggests that agri-food commodity groups with initially high $\mathrm{B}$ indices have been declining and thus revealing declining comparative advantages in agri-food trade with EU-27. As it was mentioned, the degree of change also depends on coefficient of correlation. Looking at the ratio $\beta / R$ with value 0.3319 which is lower than 1 , we can say that the degree of specialization of the UK has decreased, which means that the competitiveness of UK in the agrifood trade with EU-27 countries is falling.

Competitiveness of agri-food trade reflects the situation in agri-food sector and is influenced by many factors and circumstances that occur. If we look at the development of agriculture in the United Kingdom over the last years, we can see that the British agriculture is struggling with falling efficiency and productivity. As can be observed from global development of agriculture over the last twenty years, the main driver of agricultural growth has changed from input-based to total factor productivity based. This means ability to produce more outputs fromexisting or fewer inputs instead of increasing land area, materials use or intensifying labour. As the prices of agricultural products continue declining, this ability becomes even more important. According to
DEFRA (2016), the productivity of the UK's agriculture fell by $2.5 \%$ in 2016. During the 2001-2012 period, the UK reached an average annual growth in total factor productivity of $0.8 \%$. This value was far below the average annual growth of $2 \%$ achieved among all developed countries. Average annual growth of total factor productivity of the United States during the same period reached $2 \%$, in Germany $1.8 \%$ and in France $1.7 \%$. Compared to other countries, the UK's total factor productivity has quite stagnated since the early 1990's and this has translated into stagnation of agricultural output. Lag in productivity behind other countries can be seen especially in beef and sheep production. Although there is an increase in cattle numbers, cattle producers struggle with high production costs, especially of feedstuffs. Problems occur also in dairy industry. The UK is the third largest producer of cow's milk in the EU and besides milk, the UK exports also processed dairy products like butter, cream and cheese to EU market. However the sector has gone through many problems. It was hit by foot and mouth disease outbreaks in the early 2000s, when large numbers of UK livestock were destroyed and strict regulations were imposed on the UK livestock industries. According to DEFRA (2016), the total number of UK dairy cows has fallen from 2.6 million in 1996 to 1.9 million in 2015, which is a $27 \%$ reduction. Moreover, dairy sector faces also low prices not only in EU market but globally. In 2014, Russia banned the import of EU milk and Baltic states which were the main suppliers of milk to Russia, have decreased their prices and redirect their exports to EU market. These market fluctuations and events led to fall in the number of dairy producers and have a negative impact on competitiveness of industry. Vulnerability of 
mentioned sub-sectors also lie in deep integration in subsidies systems of EU.

\section{CONCLUSION}

In terms of agri-food trade, the EU-27 (EU28-UK) is the UK's major trading partner. Approximately $71 \%$ of all agri-food commodities are imported from EU, which means that the United Kingdom is dependent on agri-food imports from EU. On the other hand, EU is important for UK also because of exports, since the UK exports to EU market around $62 \%$ of its agri-food production. An analysis of competitiveness of the United Kingdom with respect to EU-27 markets based on Balassa index shows that there are only three agri-food categories in which UK was able to retain comparative advantage over the whole 2000-2016 period - HS 03 Fish, HS 21 Miscellaneous edible preparations, HS 22 Beverages, spirits and vinegar. In 2016, the UK had comparative advantages only in these three categories, whereas at the beginning of monitored period, in 2000 it had comparative advantages in nine categories. This implies that the competitiveness of UK's agri-food commodities on EU-27 market has been falling over time. Based on regression analysis of the Balassa index which was focused on stability of distribution of Balassa indices over time, we can also conclude that the degree of specialization in the agri-food trade between the United Kingdom and the rest of the EU has been decreasing as the number of commodity groups with a comparative advantage has been declining. In 2016, the UK reached comparative disadvantages in 21 categories. With respect to Brexit, the agrarian trade of the UK deserves special attention, since the United Kingdom is net importer of agri-food commodities and the EU is its major trading partner. Moreover, currently when it comes to agri-food trade the UK is losing its competitiveness on EU-27 market. And although the future trading relationship is still not known, in case that the UK leaves the single market of the EU, it may mean worse trading conditions and it is highly possible that agri-food products will face largest increases in trade protection which may lead to decline in both exports as well as imports.

\section{REFERENCES}

ANDERSON, J. (2011). The Gravity Model. Annual Review of Economics, 3(1), 133-160. DOI: http://dx.doi.org/10.1146/annurev-economics-111809$\underline{125114}$

BALASSA, B. (1965). Trade liberalization and revealed comparative advantage. The Manchester School of Economics and Social Studies, 33(1): 99-123. DOI: https://doi.org/10.1111/j.1467-9957.1965.tb00050.x

BANTERLE, A. (2005). Competitiveness and agri-food trade: an empirical analysis in the European Union. $11^{\text {th }}$ Congress of the EAAE. The Future of Rural Europe in the Global Agri-Food System. Copenhagen, 24-27 August 2005. Available at: http://ageconsearch.umn.edu/bitstream/24692/1/pp05ba0 $\underline{1 . p d f}$

BELLORA, C., EMLINGER, C., FOURÉ, J. and GUIMBARD, H. (2017), Research for AGRI Committee,
EU - UK agricultural trade: state of play and possible impacts of Brexit, European Parliament, Policy Department for Structural and Cohesion Policies, Brussels.

BOJNEC, Š. and FERTÖ, I. (2006). Comparative Advantages and Competitiveness of Hungarian and Slovenian Agri-Food Trade in the EU Markets. Paper presented at the 98th EAAE Semi nar Marketing Dynamics within the Global Trading System: New Perspectives. Chania, Crete, Greece, 29 June-2 July.

BOJNEC, Š. and FERTÖ, I. (2007). Hungarian and Slovenian Agro-Food Trade with Three Main European Union Partners. Ekonomický časopis/Journal of Economics, Vol. 55, no. 4 (2007), p. 345 - 358.

BOJNEC, Š. and FERTÖ, I. (2015). Agri-Food Export Competitiveness in European Union Countries. $J$ Common Mark Stud, 3: 476-492. DOI: https://doi.org/10.1111/jcms.12215

CANTWELL, J. (1989). Technological innovation and multinational corporations. Oxford: Blackwell Publisher.

CARRARESI, L. and BANTERLE, A. (2008). Measuring Competitiveness in the EU Market: A Comparison between Food Industry and Agriculture. Paper presented at the 12th EAAE Congress, Gent, Belgium, 27-30 August.

DALUM, B., LAURSEN, K. and VILLUMSEN, G. (1998): Structural change in OECD export specialisation patterns: despecialisation and 'stickiness'. International Review of Applied Economics, 12 (3): 423-443. DOI: https://doi.org/10.1080/02692179800000017

DEFRA. (2016). UK Dairy Industry Statistics. Commons Briefing papers SN02721.

DHINGRA, S., HUANG, H., OTTAVIANO, G., PESSIOA, J. P., SAMPSON, T., VAN REENEN, J. (2016). The costs and benefits of leaving the EU: Trade effects, Centre for Economic Performance, London School of Economics and Political Science.

DOWNING, E. and COE, S. (2018). Brexit: Future UK agriculture policy. Commons Briefing papers CBP-8218. Available

https://researchbriefings.parliament.uk/ResearchBriefing/ Summary/CBP-8218\#fullreport

HAAS, J. and RUBIO, E. (2017). Research for AGRI Committee - Possible impact of Brexit on the EU budget and, in particular, CAP funding. European Parliament, Policy Department for Structural and Cohesion Policies, Brussels. Available at: http://www.europarl.europa.eu/RegData/etudes/STUD/20 17/602007/IPOL_STU(2017)602007 EN.pdf

HINLOOPEN, J. and VAN MARREWIJK, C. (2001): On the empirical distribution of the Balassa index. Weltwirtschaftliches Archiv, 137 (1): 1-35. DOI: https://doi.org/10.1007/BF02707598

HINLOOPEN, J. and VAN MARREWIJK, C. (2008). Empirical relevance of the Hillman condition and the comparative advantage: 10 stylized facts. Applied Economics, Vol. 40, no. 18 (2008), p.2313-2328. DOI: https://doi.org/10.1080/00036840600949488

HM TREASURY. (2016). HM Treasury analysis: the long-term economic impact of EU membership and the alternatives. 201 p. ISBN 978-1-4741-3090-5. 
HOEN, A. and OOSTERHAVEN, J. (2006). On the measurement of comparative advantage. The Annals of Regional Science, $40 \quad$ (3), p. 677-691. DOI: https://doi.org/10.1007/s00168-006-0076-4

JAMBOR, A. (2013). Comparative advantages and specialisation of the Visegrad countries agri-food trade. Acta Oeconomica et Informatica. XVI (Number 1, 2013): 22-34. DOI: 10.15414/raae.2013.16.01.22-34

JAMBOR, A. and SURESH, B. (2016). Competitiveness of Global Agriculture. Policy Lessons for Food Security. 197 p. ISBN 978-3-319-44874-9.

KIM, D. and MARION, B.W. (1997). Domestic Market Structure and Performance in Global Markets: Theory and Empirical Evidence from U.S. Food Manufacturing Industries. Review of Industrial Organization, vol. 12, p. 335-354. DOI: https://doi.org/10.1023/A:1007776312444 LIESNER, H.H. (1958): The European common market and British industry. Economic Journal, 68: 302-316. DOI: $10.2307 / 2227597$

McGUINESS, T. and GRIMWOOD, G. G. (2017). Migrant workers in agriculture. Commons Briefing papers CBP-7987. Available at: https://researchbriefings.parliament.uk/ResearchBriefing/ Summary/CBP-7987

NALLARI, R. and GRIFFITH, B. (2011). Understanding Growth and Poverty. The World Bank, Washington D.C. 498 p. ISBN 978-0-8213-6953-1.
PITTS, E. and LAGNEVIK, M. (1998). What determines food industry competitiveness? In Traill, W.B., Pitts, E. (eds), "Competitiveness in the food industry", Blackie Academic \& Professional, London, pp. 1-34.

POTTON, E. and WEBB, D. (2017), Brexit: Agriculture and Trade, Briefing Paper 7974, UK House of Commons. PROUDMAN, J. and REDDING, S. (2000). Evolving patterns of international trade. Review of International Economics, 8 (3), $\quad$ p. $373-396 . \quad$ DOI: https://doi.org/10.1111/1467-9396.00229

RICHARDSON, D. J. and ZHANG, C. (2001). Revealing Comparative Advantage Chaotic or Coherent Patterns across Time and Sector and U.S. Trading Partner? In Topics in Empirical International Economics: A Festschriftin Honor of Robert E. Lipsey. Ed. Magnus Blomstrom and Linda S. Goldber, 195-232, Chicago: University of Chicago Press. ISBN: 9780226060835

SPRINGFORD, J. and TILFORD, S. 2014. The Great British trade-off: The impact of leaving the EU on the UK's trade and investment. Centre for European Reform. Available at: http://www.cer.eu/sites/default/files/publications/attachm ents/pdf/2014/pb_britishtrade_16jan14-8285.pdf YU, R., CAI, J. and LEUNG, P. (2009). The Normalized Revealed Comparative Advantage Index. The Annals of Regional Science, 43 (1), p. 267-282. DOI: https://doi.org/10.1007/s00168-008-0213-3 